\title{
Erratum to: Evaluation of chemical castration with calcium chloride versus surgical castration in donkeys: testosterone as an endpoint marker
}

\author{
Ahmed Ibrahim ${ }^{1 *}$, Magda M. Ali ${ }^{1}$, Nasser S. Abou-Khalil ${ }^{2}$ and Marwa F. Ali ${ }^{3}$
}

Unfortunately, after publication of this article [1] it was noticed that an incorrect version of Fig. 8 (Fig. 1 here) was introduced during the production process. The correct figure can be seen below. The original article has also been updated to reflect this.

\begin{abstract}
Author details
'Department of Surgery, Anesthesiology and Radiology, Faculty of veterinary medicine, Assuit University, Assuit 70155, Egypt. ${ }^{2}$ Department of Medical physiology, Faculty of medicine, Assuit University, Assuit, Egypt. ${ }^{3}$ Department of Pathology and clinical pathology, Faculty of veterinary medicine, Assuit University, Assuit, Egypt.
\end{abstract}

Received: 10 March 2016 Accepted: 10 March 2016

Published online: 23 March 2016

\section{Reference}

1. Ibrahim A, Ali M, Abou-Khalil N, Al M. Evalutation of chemical castration with calcium chloride versus surgical castration in donkeys: testosterone as an endpoint marker. BMC Veterinary Research. 2016;12:46.

\footnotetext{
*Correspondence: elgrah38@gmail.com

'Department of Surgery, Anesthesiology and Radiology, Faculty of veterinary medicine, Assuit University, Assuit 70155, Egypt

Full list of author information is available at the end of the article

Submit your next manuscript to BioMed Central and we will help you at every step:

- We accept pre-submission inquiries

- Our selector tool helps you to find the most relevant journal

- We provide round the clock customer support

- Convenient online submission

- Thorough peer review

- Inclusion in PubMed and all major indexing services

- Maximum visibility for your research

Submit your manuscript at www.biomedcentral.com/submit 


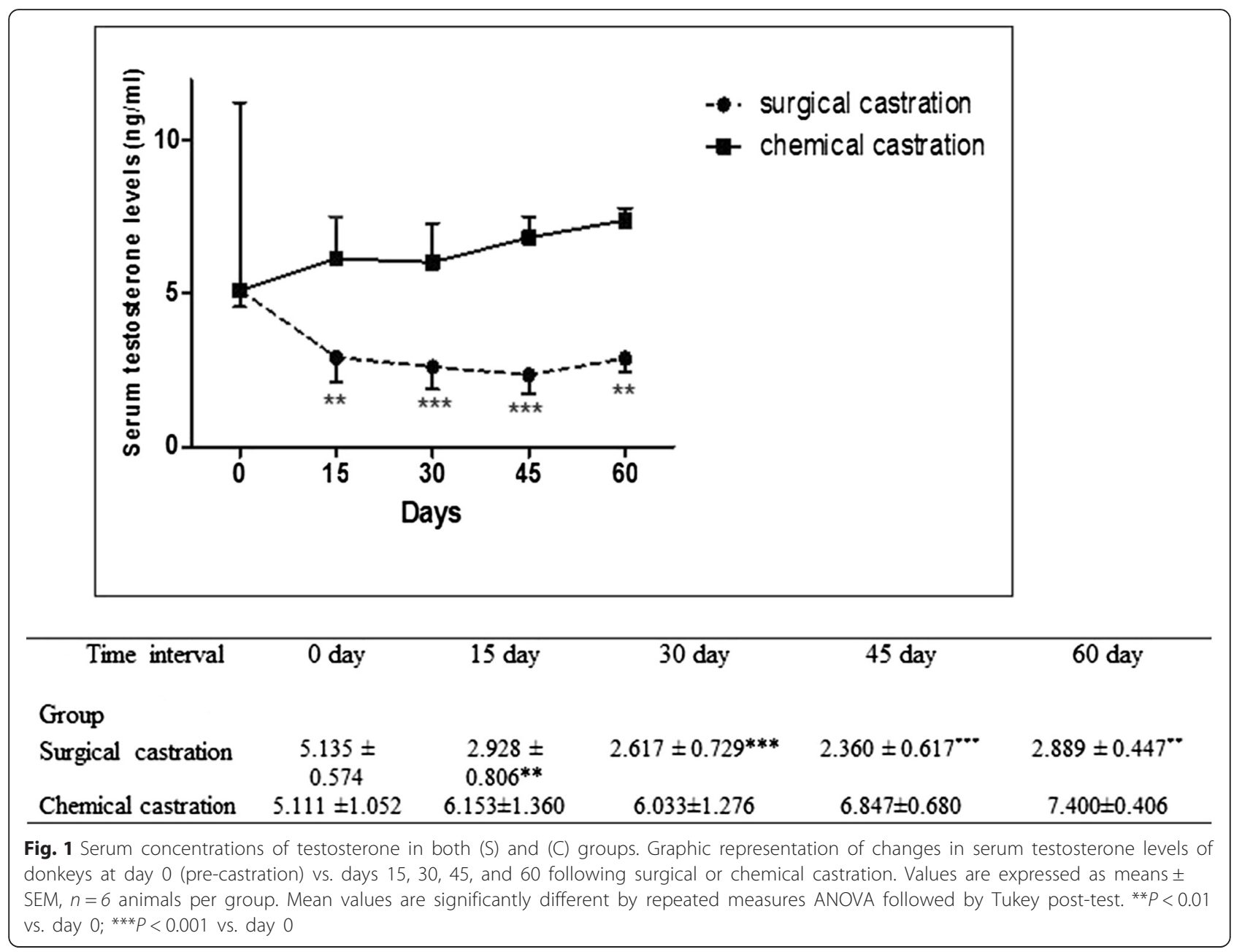

